\title{
Street Crime during Covid-19 Pandemic in Perspective of Routine Activity Law Theory and it Influence on Indonesian Criminal Law
}

\author{
Ida Hasan ${ }^{1 *}$, Holy One Singadimedja ${ }^{2}$, Yogi Yasa Wedha ${ }^{3}$, Sara Ida Magdalena Awi ${ }^{4}$, \\ Edy Nurcahyo ${ }^{5}$ \\ ${ }^{1-2}$ Faculty of Law, Universitas Singaperbangsa Karawang \\ Jawa Barat, Indonesia \\ ${ }^{3}$ Faculty of Law, Udayana University \\ Bali, Indonesia \\ ${ }^{4}$ Faculty of Law, Jayapura Cenderawasih University \\ Papua, Indonesia \\ ${ }^{5}$ Faculty of Law, Universitas Muhammadiyah Buton \\ Sulawesi Tenggara, Indonesia \\ *Corresponding Authors: \\ E-mail: ida.rhasan@fh.unsika.ac.id
}

\begin{abstract}
The initial prediction is that the condition of covid-19 pandemic will shake people's lives in all aspects, and this condition has a great potential for rising crime. With all of its character, it is very interesting to discuss how street crime developed during the Covid-19 pandemic. This study use a mixed research method, where data is collected from facts in the field, legal sources or applied regulations, associated with legal materials obtained from literature review research and overall data obtained from both primary data and secondary data. The conclusion from this research is that street crime during the Covid-19 Pandemic cannot be stated expressly decreased or increased for each region has dynamics that differ from one another according to the characteristics of the region. The correlation of PSBB policy during the Covid-19 Pandemic with the level of street crime in the perspective of routine activity theory can be seen from several street crimes that change the type and location of their objects / targets as well as the increasing number of drug and cybercrime cases that are striking. PSBB conditions during Pandemic Covid-19 against crimes that require a new system that is integrated with the internet, a pattern of punishment with massive amounts of assimilation to reduce the density of prison and a virtual court examination system that should be a part of the criminal justice system in Indonesia
\end{abstract}

Keywords: Street Crime, Routine Activity Theory and Criminal Law

\section{INTRODUCTION}

Street crime is dominated by crimes against bodies and lives, crimes against property, crimes against public security and public order, crimes against morality and narcotics crimes.

Due to its direct contact with society lives, every increase in this crime trend has a direct and disturbing impact on society.

Based on the form of its activities, street crime divided into 2 (two) types; crimes involving violence such as murder / murder, rape / rape, assault / assault, robbery / robbery, and kidnapping (predatory street crimes) [1] and crimes against property without violence, such 
as drug crimes (non predatory street crimes) [2]. The initial prediction is that the condition of covid-19 pandemic will shake people's lives in all aspects, and this condition has a great potential for rising crime.

With all of its characteristics, it is very interesting to discuss how street crime developed during the Covid-19 pandemic, so identification of the problem formulated as follows:

a. How was the condition of Street crime during the Covid-19 Pandemic?

b. What is the correlation between PSBB policies during the Covid-19 Pandemic with the level of street crime in the perspective of routine activity theory?

c. How does the condition of the PSBB during the Covid Pandemic -19 affect the development of Indonesian Criminal Law?

\section{METHODS}

This study use a mixed research method, where data is collected from facts in the field, legal sources or applied regulations, associated with legal materials obtained from literature review research and overall data obtained from both primary data and secondary data.

\section{HASIL DAN PEMBAHASAN}

\section{a. Conditions of Street Crimes During the Covid-19 Pandemic}

According to Prof. Harkristuti, the earlier prediction which assumed the Covid-19 pandemic period would lead to a wave of crime in community in reality did not occur nationally. This can be seen in the table below.

Table 1.

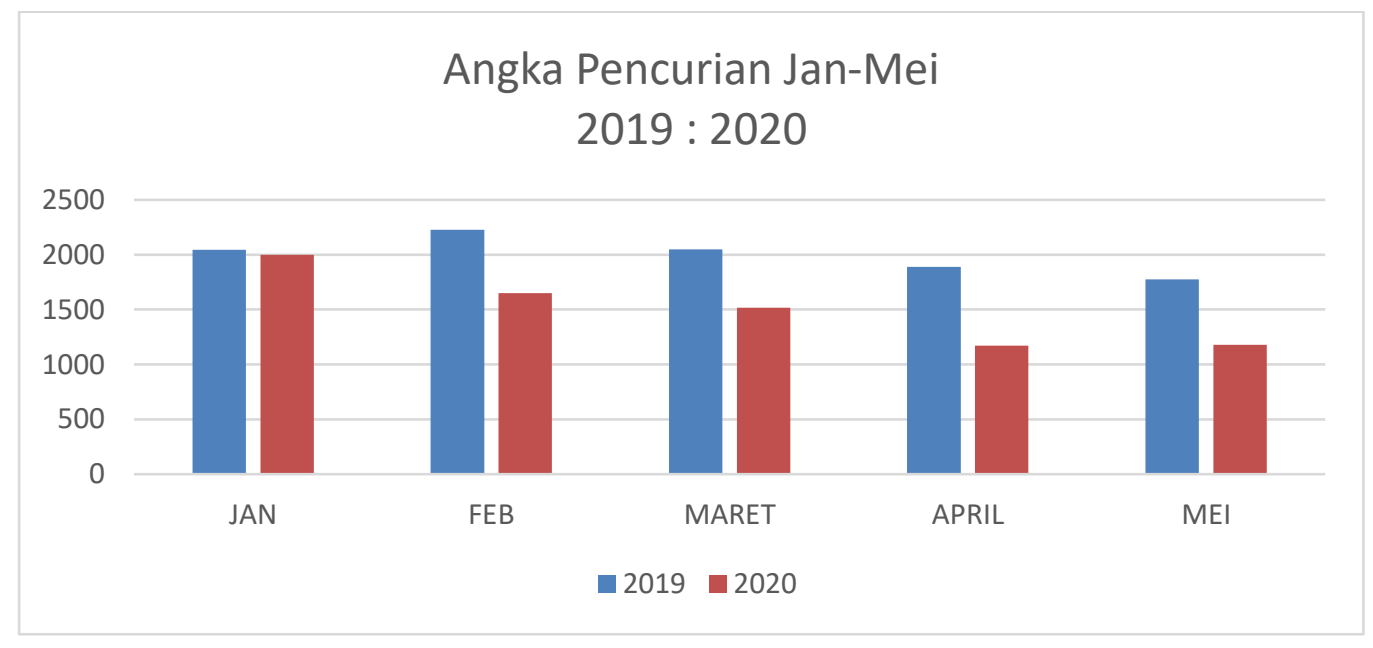

Source: The Police Of The Republic Of Indonesia [2].

If theft crimes can be described as a reflection of street crime, then the Republic of Indonesia National Police statistics compared the number of crimes in 2019 with 2020 shows a significant decrease in the number of criminal acts of theft. Even the comparison data in April when the pandemic peaked, the crime rate dropped quite sharply by 37\% (a decrease of 717 cases) from 1888 cases in April 2019 to 1171 cases in April 2020.

However, the national data above cannot directly describe the full condition of each region, because the level and distribution of crime in the region reflects; local community conditions and its structure, regional characteristics and local values. 
The picture in table 1 above is different from the picture in table 2 that is displayed by Prof. Marcus in the same seminar.

Table 2. Data Street Crimes before and during the Pandemic Covid-19 in Polda DIY

\begin{tabular}{|l|l|l|l|l|l|l|l|l|l|l|}
\hline No & Unity & \multicolumn{2}{|l|}{$\begin{array}{l}\text { Data Case 1 December 2019 s.d 28 } \\
\text { Feb 2020 }\end{array}$} & \multicolumn{2}{l|}{ Data Case 1 Maret 2020 s.d 31 Mei 2020} \\
\hline & Curat & Curas & $\begin{array}{l}\text { Cur } \\
\text { Ranmor }\end{array}$ & $\begin{array}{l}\text { Cur } \\
\text { Biasa }\end{array}$ & $\begin{array}{l}\text { Aniaya/ } \\
\text { Keroyok }\end{array}$ & Curat & Curas & $\begin{array}{l}\text { Cur } \\
\text { Ranmor }\end{array}$ & $\begin{array}{l}\text { Cur } \\
\text { Biasa }\end{array}$ & $\begin{array}{l}\text { Aniaya/ } \\
\text { Keroyok }\end{array}$ \\
\hline Dirkrimum & - & - & - & - & - & - & - & - & - & - \\
\hline $\begin{array}{l}\text { Resta } \\
\text { YKA }\end{array}$ & 12 & 3 & 22 & 24 & 15 & 2 & 3 & 17 & 15 & 26 \\
\hline Res. SLM & 53 & 11 & 25 & 66 & 50 & 53 & 11 & 25 & 66 & 50 \\
\hline Res. BTL & 32 & 9 & 4 & 19 & 28 & 46 & 6 & 21 & 22 & 33 \\
\hline Res. KLP & 25 & 1 & 7 & 16 & 9 & 13 & 4 & 8 & 21 & 4 \\
\hline Res.GNK & 7 & 1 & 3 & 0 & 0 & 8 & 0 & 6 & 3 & 5 \\
\hline & 129 & 25 & 61 & 125 & 102 & 122 & 24 & 77 & 127 & 118 \\
\hline
\end{tabular}

\section{Source : Polda DIY}

If seen from the second table (Table 2), it can be seen that the trend of crime is not the same depending on the character of each region. In Bantul, crime seems to have increased except for theft with violence. But in the Yogyakarta region there is a trending decline except for the crimes of persecution and beatings.

Prof. Harkristuti explained, the conditions varied depend on regional characteristics and can also be seen from media headlines which include;

Head Line In April 2020

1) The Police stated the crime rate in Indonesia rose of 16.16 percent (Kompas 06 April 2020)

2) Corona Emergency, crime actually increased during February-March (Suara.com, 12 April 2020)

3) The crime rate in Jakarta fell during the pandemic COVID-19 (Tempo, 9 Aprl 2020)

4) Street Crime in Malang is increased (Jatim pos, 14 April 2020)

5) The crime rate dropped as much as $4.32 \%$ on week 15 (Kompas, 16 April 2020)

The Head Line In The Month Of May 2020

1) The Numbers of Street Crimes increased during the Pandemic Covid-19 but the crime rate decreased by $19.9 \%$ (Okezone, 04 Mei 2020)

2) The Pandemic in North Sumatra: Street Crime Decreased But illegal Drug is Increased (Medan headlines.com, 19 Mei 2020)

3) The Number of cases of crime in Malang tend to rise, the 450 inmates received assimilation (Liputan6, 13 Mei 2020)

4) The Police Record crime figures soaring 442 Cases After Eid (CNN Indonesia 24 Mei 2020) 
5) Criminality in the Middle of a Pandemic since the beginning of May rose 7\% (Merdeka, 18 Mei 2020)

Head Line Crimes The Month Of June 2020

1) Drug and hoax cases increase in DKI during covid-19 pandemic(Tempo, 2 Juni 2020)

2) Street Crime Is Increasing in the last One Week (Alinea.ID, 3 Juni 2020)

3) Terrorism Arrests Decreased by January 2020180 people, June 202084 people (bkpsdm.palangkaraya.go.id, 16 Juni 2020)

4) Crime rate RI Decreased in April to May 2020 (Liputan 6, 8 Juni 2020)

5) Satresnarkoba Polresta Denpasar revealed 97 Drug cases and arrested 120 suspects (bkpsdm.palangkaraya.go.id, 16 Juni 2020)

From the headlines a few months, you can read the some assumptions as follows;

1) The crime trend in the Covid-19 Pandemic period is not easy to conclude that there has been an increase or decrease

2) National level data do not always reflect regional level data

3) Certain types of crime increase in certain regions, but decrease in other regions

4) Covid-19 Protocol Policy may reduce street crime rates, but can also increase other crimes

5) The crime rate reported to the National Police cannot be released from the condition of the Covid-19 pandemic

\section{1) Correlation between Covid-19 Protocol Policy and the Crime level}

The Covid-19 protocol which dramatically reduces the level of community activity is the "Work From Home" and "Social Distancing" pattern. With these two protocols, the quantity of community activity is much reduced, so that the opportunity / probability of the occurrence of crime on the streets according to these assumptions will also be reduced along with the movement of people who stay more at home. Therefore, it can be said that the level of policy linkage between the Covid-19 Protocol and the crime rate is determined by the extent to which the discipline of work from home and social distancing is implemented and enforced by local government officials. The level of community discipline and enforcement by local government officials can be seen from the attitudes and statements of the leaders and local leaders of the issue of handling the Covid-19 protocol. The more intensive and consistent the attitude of the leaders and regional leaders, the better the level of understanding, awareness and discipline of the public about the dangers of the spread of Covid 19. This is important because one of the causes of public indiscipline is the disinformation of social media that proclaims Covid-19 is a hoax and conspiracy against people with limited knowledge about covid-19. Beyond that, the reduction in crime rates could occur not because of the absence of crime, but because the level of crime reporting by the community is declining in impact from the Covid-19 protocol which limits the activities of residents outside the temporary home to date, crime reporting procedures must remain directly face-to-face. Besides that, there is a possibility that the crime rate will also decrease due to impact of social distancing toward performance of law enforcement officers so that they tend to avoid arrest / detention. Prof. Harkristuti Harkrisnowo described the tendency to decrease the level of street crime in various countries during the pandemic [3]; 
1) Italy: the number of crimes reported between March 1st and March 22nd droppdes by 64\% comparedwith the same period in 2019

2) New York City: grand larceny declined by over 50\% in April compared to the same periode lat year, however, commercial burglariesrise despite the overall fall of $-29 \%$ in major crimes

3) Chicago: drug arrests have fallen 42\% since the lockdown, comparewith the same period in 2019, and crime total has declined 10\% following the outbreak of the pandemic.

4) India: Police seized thousand of fake N95 masks, raided shops selling overpriced masks and sanitizers, and initiated case against hoarders of personal protective equipment.

5) Europol: The pandemic has caused a decrease in some organized-criminal activities, while providing new opportunities in other areas, causing a change in the organizedcriminal senonomy that may be be long term.

Philippines: Crime incidents across the archipelago had dipped sharply during the 84-day locdown imposed since mid March to control the spread of the novel corona virus.

\section{2) Street Crime in the Perspective of Routine Activity Theory}

This theory is based on the writings of Lawrence E. Cohen and Marcus Felson in 1979 titled "Social change and crime rate trends: A routine activity" [4]. Lawrence E. Cohen and Marcus Felson said that "most criminal acts require convergence in space and time of likely offenders, suitable targets and the absence of capable guardians against" Street crime can occur if there are 3 (three) following aspects [5]: 1) suitable target, 2) Motivated offender 3) Absence of capable guardian [6]. In this case, it can be explained that crime occurs when the three elements are intertwined and interconnected. Motivated person are people (individuals or groups) who not only have the ability to carry out criminal actions, but also have the intention and plan to carry them out. Capable guardians include people or objects that deter crime, police, dogs, neighborhood time, alarm systems and locking devices [7]. While Suitable target is a person or object of interest. According to Burke, suitable targets can include people, objects and places. So the victims here are not always people, but also objects and places. Below is a conceptual model of the Routine activity theory and its elements [8].

\section{The Routine Activity Theory Classic Basic Crime Triangle}

\section{The Chemistry for Crime}

Motivated, likely and capable offender

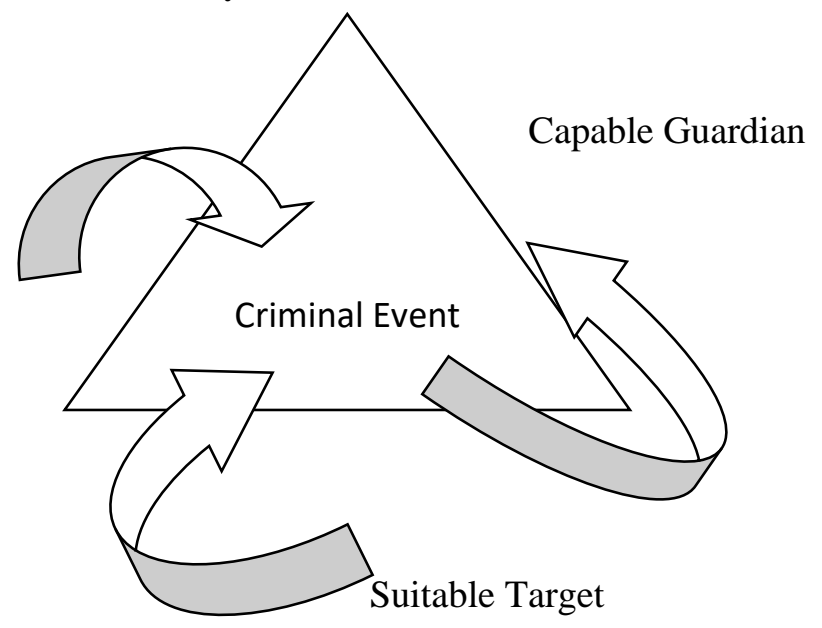


Regarding motive as a cause of committing crime, Thomas $\mathbf{J}$ Bernard stated that there is no direct causal relationship between crime and poverty because crime rates do not consistently increase when poverty levels increase, or vice versa when poverty rates do not necessarily decrease crime rates.

Crime is not always related to social problems such as poverty, unemployment and social inequality. However, changes in socioeconomic conditions will affect the level of crime and victimization

The routine activities of perpetrators and victims play a role in crime. The risk of becoming a victim will be even greater if there is a lack of security or no security at all. including lifestyle will provide opportunities towards victimization.

\section{b. Correlation between the PSBB Policy during the Covid-19 Pandemic with the level of street crime in the perspective of routine activity theory. \\ 1) The Impact of the PSBB Policy during the Covid-19 Pandemic and Predatory Crime}

The PSBB policy has caused changes in the way of life of the community, the more people inside the house will minimize interaction with people outside the home so that it reduces the possibility of becoming a victim of street crime.

The object of crime is no longer on individuals who carry out activities or trips outside the home, but increases the opportunity for potential offenders to commit crimes against business locations that are opened, for example, a mini market where visitors are rarely seen due to the impact of PSBB.

In addition, the impact of limiting activities makes the road more lonely and lonely place has the potential to create a crime against individuals who force themselves out of the house for urgent reasons.

Limitation of outside activities has the potential to increase the likelihood of Domestic Violence (domestic violence) due to proximity and stress. This is in line with the results of James M. Manon's study which states that long end of year holidays and Christmas have the risk of domestic violence due to boredom because being in a limited environment for a longer period of time triggers feelings of stress, frustration and boredom can also increase emotional levels that high. And the pressure of financial needs that increase when all family members gather without productive activities [9]. Especially when conflict situations or circumstances that cause instability in the potential for domestic violence will be even greater [10].

\section{2) Impact of PSBB Policy during the Covid-19 Pandemic and Cyber Crimes}

The Covid-19 protocol in the form of the PSBB policy severely limits the movement of the community to activities outside, so that more people do activities by working at home. The need to obtain information, access services including making purchases of household and personal needs which are usually done offline now relies on the internet through an online system.

Exploiting people's fear of the impact of a pandemic, changing lifestyle patterns have their own consequences in the form of increasing opportunities for crime against tangible property in the form of cyber crime such as fake applications, fake domain names and websites, 
online fraud malware attacks. This has the potential to open space for the occurrence of information crimes: online disinformation, hoaxes, hate crimes. Especially with the character of cyber space that is not well understood by internet users in Indonesia, that often ignores the security system. As stated by Faizin that according to research conducted by Yang with reference to the routine activity theory shows that the increase in cyber crime is influenced by the level of security / security of computer systems in activities carried out by users [11]. In previous tables that, we can see the facts range from March to June 2020, cybercrimebased crime is increasing, especially in Jakarta and big cities.

\section{c. The Effect of the PSBB Policy during the Covid-19 Pandemic on the development of Indonesian Criminal Law}

The condition of the people who have to follow the Covid-19 protocol with the PSBB policy directly has caused a shift in criminal justice, both in the process of making police reports by victims, criminal proceedings in Penitentiaries and examining virtually criminal cases in court.

\section{1) The level of crime reporting that requires a face to face condition is likely to decrease}

Data on the accumulation of crime rates as shown in table 1 shows a decreasing trend of theft of crimes. There are two possibilities; first, it is true that due to the PSBB policy, the activities of the community to go out are limited, so that the house as a place to live is always full of residents, resulting in opportunities for perpetrators of theft to be limited. Including deprivation crime (snatches, pickpockets, robbery) is reduced because there are no people who work outside the home.

However, if seen from criminological theories that often link economic factors and poverty to be the main triggers of crime, it is possible that the actual crime rate did not decrease or even increased, but the crime that occurred was not reported by the victim. This is possible because the police reporting process is still offline, which requires victims to come directly to the police station. While the PSBB policy psychologically has a very strong impact on the community not to leave the house. As result, in a crime where the level of loss / damage was considered minor / minor / minor, the victim would most likely not prolong the problem by making a police report. Based on this fact, it is about time, the procedure for making police reports began to be developed in two ways, in addition to face-to-face / offline as it is today, it is also needed to make an application that allows victims to do police reports online.

\section{2) rates in prisons decreased with the provision of assimilation and integration for nearly 40,000 inmates}

At the beginning of the Covid-19 pandemic, to avoid the spread of the virus in the prison environment in Indonesia which is known to have an overcapacity condition, the government has carried out an assimilation policy of 40,000 inmates. This policy is a new thing in Indonesia, initially received a variety of responses from the public, especially those who fear that prisoners will commit various crimes after they are released. This is understandable because our criminal system which is a Dutch colonial legacy is more likely to punish perpetrators. But in reality during the co- 19 pandemic, there were only 400 recorded crimes committed by former convicted prisoners. Compared to the number of assimilation recipients as many as 40,000 people, the repetition rate can be said to be very small which shows the system of guidance in correctional institutions and social control in the community is 
running effectively. This can be used as a starting point for the renewal of criminal law in Indonesia, which was stalled when the new KUHP was postponed.

\section{3) Virtual Inspection}

The Covid-19 Protocol, which severely limits the collection of many people in one room, creates difficulties for law enforcement officials to carry out their functions, including during hearings in court trials. In recent times a virtual trial pattern has been conducted which is new in Indonesia. This is interesting to be examined legally, because it is not regulated in the Criminal Procedure Code which forms the basis of formal criminal law. This also includes Supreme Court Regulation no. 1 of 2019 that only regulates trials with the help of information technology in civil cases, religious cases, military administration and state administration. (Article 3 paragraph (1) PERMA No. 1 of 2019). Although a virtual examination at a court hearing has enormous benefits in serving law in a pandemic, the principles of procedural law which strictly forbid everything to be done without a legal basis must still be obeyed. Therefore, this Covid-19 pandemic moment, could be a starting point to continue to refine the criminal justice system in Indonesia, including the provision of a virtual hearing examination.

\section{CONCLUSION}

The condition of Street crime during the Covid-19 Pandemic cannot be stated explicitly decreasing or increasing for each region has dynamics that differ from one another according to the characteristics of the region. There are several types of crime recorded to decrease, but in other types of crime increased.

Correlation between PSBB policy during Pandemic Covid-19 and the level of street crime in the perspective of routine activity theory can be seen from several street crimes which according to changing their object / target, which initially stolen to the house switched to a 24-hour supermarket, the increase in drug and cybercrime cases is striking. The condition of the PSBB during the Covid-19 Pandemic to the development of Indonesian Criminal Law, particularly in the need for a crime reporting system that requires a new system integrated with the internet, a pattern of punishment with assimilation in a massive amount to reduce the density of correctional institutions and a virtual justice inspection system that must be virtually become part of the criminal justice system in Indonesia

\section{REFERENCE}

[1] Erlina, Analisa Kriminologi Terhadap Kekerasan Dalam Kejahatan, al daulah, Vol.3/No.2/Desember 2014, hlm. 219.

[2] Seminar Nasional MAHUPIKI, Jakarta, 15 Juni 2020

[3] Seminar Nasional MAHUPIKI, ibid

[4] Cohen, L., and Felson, M. Social change and crime rate trends: A routine activityapproach. American Sociological Review vol. 44 pp. 588-608. (1979).

[5] Yusnarida Eka Nizmi, Analisa Routine Activity Theory Dalam Perdagangan Seks Di Thailand, China Dan Vietnam, Sorot, Vol 6, No 1, April 2011, hlm. 35.

[6] Sujung Cho, Explaining Physical, Verbal, and Social Bullying among Bullies, Victims of Bullying, and Bully-victims: Assessing the Integrated Approach between Social Control and 
Lifestyles-Routine Activities Theories, Children and Youth Services Review,Cysr (2018), hlm.9. doi:10.1016/j.childyouth.2018.06.018

[7] Dwi Haryadi, Identifikasi Faktor Kriminogen Kejahatan Seksual di Propinsi Kepulauan Bangka Belitung dengan Routine Activity Theory, Prosiding Call Paper Pada Simposium dan Pelatihan Hukum Pidana dan Kriminologi ke IV, Rekonstruksi Hukum Mengenai Kejahatan Seksual Terhadap Perempuan dan Anak, Tindak Pidana Perdagangan Orang dan Tindak Pidana Pencucian Uang,Kupang, 2017, hlm 12

[8] Burke, T. 2009. Routine Activity Theory. In Janet K. Wilson (Ed). The Praeger Handbook of Victomology, Santa Barbara, California: Praeger.(hlm. 232-233).

[9] James M. Mannon, Domestic and Intimate Violence: An Application of Routine Activities Theory, Aggresion and Violent Behavior Journal, Vol.2.No. 1, hlm. 11

[10] Harkristuti Harkrisnowo, Domestic Violence (Kekerasan Dalam Rumah Tangga) Dalam Prespektif Kriminologis dan Yuridis, Indonesian Journal of International Law, Volume 1 Nomor 4 Juli 2004, hlm 10

[11] Faizin Sulistio, Hukum Pidana dalam Perspektif, Denpasar: Pustaka Larasan; 2012 hlm. 134 